\title{
Guidelines to Promote Local Community Participation in Developing Agrotourism: A Case Study of Ban Mor Village, Sam Sung District, Khon Kaen Province, Thailand
}

\author{
Thirachaya Maneenetr ${ }^{1}$, Aree Naipinit ${ }^{1} \&$ Thanh Ha $\operatorname{Tran}^{1}$ \\ ${ }^{1}$ Faculty of Management Science, Khon Kaen University, Khon Kaen Province 40002, Thailand \\ Correspondence: Thirachaya Maneenetr, Faculty of Management Science, Khon Kaen University, Khon Kaen \\ Province 40002, Thailand. E-mail: thirachaya@kku.ac.th
}

Received: January 26, 2014

Accepted: March 13, 2014 Online Published: April 29, 2014

doi:10.5539/ass.v10n9p178

URL: http://dx.doi.org/10.5539/ass.v10n9p178

\begin{abstract}
This article aims to study local community participation in agrotourism and propose guidelines to promote local community participation in developing agrotourism in Ban Mor Village, Sam Sung District, Khon Kaen Province, Thailand, which is an agricultural village based on the Sufficiency Economy Philosophy. The researchers used both quantitative and qualitative methods. The results show that there were high levels of local community participation in agrotourism in term of accessibility (S.D. $=.30$ ), attraction (S.D. $=.39$ ), activities $($ S.D. $=.40)$, attitudes (S.D. $=.32)$, accommodation (S.D. $=.25)$, amenity (S.D. $=.34$ ) and advertising (S.D. $=.33$ ). The guidelines that were proposed to promote local community participation in the development of agrotourism included: 1) promoting agrotourism in the Ban Mor Village through advertising 2) improving local facilities to respond tourists' needs and expectation, 3) establishment of a local agricultural learning center 4) building agrotourism networks, and 5) promoting the roles of the young members of the community in agrotourism.
\end{abstract}

Keywords: local community participation, agrotourism

\section{Introduction}

Community development has been introduced as an important approach to rural development (Sebele, 2010). Because of the decline of traditional industries, some rural communities must explore alternative means of recovering and expanding their local economies based on community resources. Agrotourism is a viable choice in rural areas. Agrotourism is more than a tourist product (Busby \& Rendle, 2000). It brings a new awareness and, a positive attitude toward the local environment, local community and local culture (Lopez \& Garcia, 2006).

The promotion of agrotourism in Thailand officially started in 1995. At present, more than 400 agricultural villages have been promoted as agrotourism destinations, and a number of potential communities are currently being developed for agrotourism (Na Songkhala \& Somboonsuke, 2013). Ban Mor Village is located on in Sam Sung District of Khon Kaen Province in Thailand. This agricultural area transferred from traditional agriculture to organic agriculture in 1995. Currently, Ban Mor Village is known for its organic farm produce. This village is also an emerging destination for agrotourism.

However, once a community becomes a tourist's destination, the lives of the residents in the community become affected by tourism activities (Jurowski et al., 1997). To achieve effective tourism management, community participation is often regarded as one of the most essential requirement (Lea, 1988). This belief is consistent with the opinion of Allen et al. (1998) who stated that tourism development based on local communities can attain sustainability, but the residents must be willing partners in the process. When local people participate in the destination management process, they will have a chance to gain benefits from the tourism taking place, sharing their local knowledge and ideas and conserving local resources (Tosun, 2006).

Therefore, in this study, the researchers focus on the problems of local community participation in tourism development in Ban Mor Village, which is located in Sam Sung District of Khon Kaen Province in Thailand. In this respect, two questions were raised: 1) what problems there are regarding local community participation in agrotourism in Ban Mor Village, and 2) what guidelines there should be to promote local community participation to develop agrotourism in Ban Mor village, Sam Sung district, Khon Kaen Province. 


\section{Literature Review}

\subsection{Agro Tourism in Ban Mor Village, Sam Sung District in Khon Kaen Province}

Marques (2006) stated that agrotourism is a special type of rural tourism in which the hosting house must be integrated into an agricultural estate and, inhabited by a proprietor who allows visitors to take part in agricultural or complementary activities on the property. Agrotourism development has positive impacts on tourists and local communities. For tourists who love nature and rural environments, agrotourism provides them with a chance to experience agricultural activities (Tew \& Barbiere, 2012). For the local community, agrotourism brings additional benefits such as stimulating local business (Tew \& Barbiere, 2012), and increasing awareness and preservation of local customs and unique cultural traits (Ollenburg \& Buckly, 2007). These reasons are why agrotourism is a crucial mechanism to stimulate rural development.

Nowadays, the traditional definition of agrotourism has expanded to include a set of activities that occur when people link travel with products, services and experiences of agriculture (Maetzold, 2002). This also seems to include commercial tourist activities. In terms of sustainable development, tourist activities should respect and preserve the natural, cultural and social integrity of the area in the long term (World Tourism Organization, 2004). This is why organic agotourism was created. This type of tourism is based on ethical values with attention to the economic, environmental and social impact of the tourists' activities (Goodwin \& Francis, 2003).

Ban Mor Village is an agricultural community which applied the Sufficiency Economy Philosophy developed by the King of Thailand to highlight a balanced way of living (Mongsawad, 2010). This philosophy was founded on sustainable farming issues, which focus on step-by-step economic development and on ensuring the majority of the rural community has enough resources on which to subsist as the first priority (The Chaipattana Foundation, n.d.). Ban Mor Village transferred from traditional agriculture to organic agriculture which is a cultural evolution with its origins in an environmentalist culture (Ritson \& Oughton, 2006). It also focuses on the quality of agricultural product and places consideration on providing healthful food for consumers (Hjelmar, 2011). Transferring to organic agriculture increase the income of the local community in Ban Mor Village and created image of an organic agriculture destination for tourists. At present, many tourists visit the village to experience the fresh atmosphere of the destination and learn about organic farm processes. This enables the local community to gain additional income from agrotourism activities.

\subsection{Tourism Destination}

Destinations are places where people choose to travel to and stay during their holiday to experience certain features or characteristics - a perceived attraction of some sort (Leiper, 1995). Most destinations comprise a core of the following components which can be characterized as the six as framework includes attraction, accessibility, amenity, available package, activities, and ancillary services. This framework is a combination of all the services and, ultimately, experiences provided locally (Buhalis, 2000). In addition, accommodation business also plays a significance role in aiding the success of the tourism industry in terms of providing an important component of the travel decision (Ahmad et al., 2014). These are the fundamental elements that respond to the tourists' needs and expectations with regard to a destination.

The collection of fundamental elements to create a unique image of a destination for the purpose of communicating with and attracting tourists is a crucial issue in tourism management. This is how advertising plays an important role in tourism management, by informing, pursuing and reminding tourists (Morrison, 2013). As Monsef \& Raji (2013) stated advertising is truly a magical process of creating connections between customers' emotions and customers' behaviors in the tourism decision process.

However, each of tourism destinations has differentiated from its resources, such as accommodation, attraction and activities. Therefore, appropriate guidelines for tourism management should focus on existing resources to create the most effective results.

\subsection{Local Community Participation in Tourism Development}

Tourism is increasingly recognized for its potential in fostering rural economic development (Jackson \& Murphy, 2006). Tourism leads to many opportunities in rural areas (Ritchie \& Inkari, 2006) such as increasing the economic viability of marginalized areas, stimulating social regeneration and improving the living conditions of rural communities (Briedenhann \& Wickens, 2004). Conversely, the attitudes of the local community also directly affect the current and future tourism development. More increased local involvement and participation will help to ensure that communities are empowered and conserve their local resources (Sebele, 2010). Therefore, the role of the community is concerned with maximizing the benefits and minimizing the negatives impacts on the host community (Ritchie \& Inkari, 2006). 
Local community participation includes the empowerment and involvement of communities in decision-making implementation and identifying local problems (France, 1998), which is crucial for developing tourism in rural areas. Participation is emphasized in order to facilitate physical development, to ensure the inclusion of the communities' wishes in tourism planning and development, and to ensure economic returns (Murphy, 1985). Sharing opinions in the tourism planning process, local communities have chances to identify how their local resources are used appropriately in tourism activities. This is consistent with the findings of Ritchie \& Inkari (2006) who stated that the community involvement provides a strong level of support for tourism development in terms of economic, social and environmental benefits.

\section{Objectives}

1) To study local community participation in agrotourism in Ban Mor Village, Sam Sung District, Khon Kaen Province.

2) To study the guidelines to promote local community participation in the development of agrotourism in Ban Mor Village, Sam Sung District, Khon Kaen Province.

\section{Research Methodology}

To ensure the study was objective, the researchers employed quantitative research methods, qualitative research methods or a mixed method approach as shown below.

\subsection{To Study Local Community Participation in Agro Tourism in Ban Mor Village, Sam Sung District, Khon Kaen} Province

For quantitative data collection, the participants were members of the local community who live in Ban Mor Village. The questionnaire consisted of two parts: 1) demographic information including sex, age, educational level, marital status and income; and 2) opinions about local community participation in agrotourism which was divided into 7 aspects: attitudes, attraction, accessibility, accommodation, activities, amenities and advertising. The questionnaire used a Likert scales with five options: strongly agree, agree, not sure, disagree and strongly disagree. The researchers interpreted the completed questionnaires by dividing the question scale into a 5 point scale, as shown in table 1:

Table 1. Significance of points

\begin{tabular}{ll}
\hline Average Scores & Levels of Significant \\
\hline $1.00-1.80$ & Lowest \\
$1.81-2.60$ & Low \\
$2.61-3.41$ & Medium \\
$3.52-4.20$ & High \\
$4.21-5.00$ & Highest \\
\hline
\end{tabular}

To calculate the sampling size, we used quota sampling. As of 2012, there were 196 households in Ban Mor Village, Sam Sung District in Khon Kaen Province (Sam Sung District Agricultural Extension Office, 2012). The researchers used quota sampling with people aged over 15 years old. The sampling size was 100 . For the statistical analysis of data, the mean, standard deviation and Chi-square test were used.

4.2 To Study the Guidelines to Promote Local Community Participation in the Development of Agrotourism in Ban Mor Village, Sam Sung District, Khon Kaen Province

For qualitative data collection, a focus group discussion was organized. There were ten experts including academics, tourism entrepreneurs, representatives of involved public organizations and local philosophers. The group discussed the appropriate guidelines for promoting local community participation in the development of agrotourism in Ban Mor Village, Sam Sung District, Khon Kaen Province. Data analysis was performed using descriptive analysis.

\section{Research Area}

Ban Mor Village is located in Sam Sung District, which is part of the Khon Kaen Province of Thailand (shown in figure 1). This village is known as an agricultural area with producing organic farm produce. Nowadays, this village becomes an agrotourism destination for anyone who would like to study organic farming as well as for 
tourists who come to relax in a rural destination.
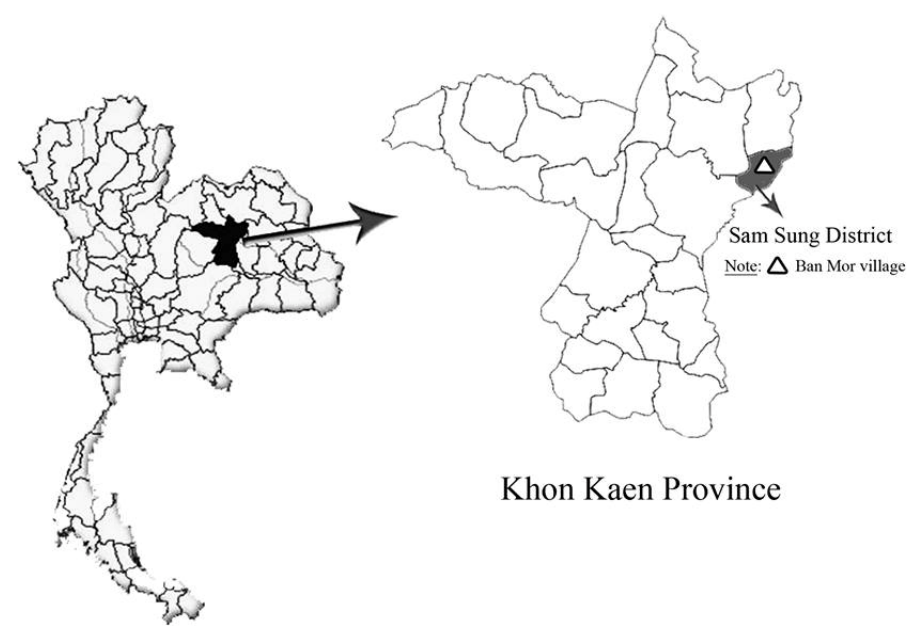

Khon Kaen Province

Thailand

Figure 1. Research area

\section{Research Result}

6.1 Local Community Participation in Agro Tourism in Ban Mor Village, Sam Sung District, Khon Kaen Province

Table 2. Local community participation in agro tourism in Ban Mor Village, Sam Sung District, Khon Kaen province

\begin{tabular}{|c|c|c|c|c|c|c|c|c|c|}
\hline \multirow[t]{2}{*}{ Items } & \multicolumn{5}{|c|}{ Participation of local communities } & \multirow{2}{*}{$\begin{array}{c}\text { Total } \\
\%\end{array}$} & \multirow{2}{*}{$\bar{x}$} & \multirow{2}{*}{ S.D. } & \multirow{2}{*}{ Interpretation } \\
\hline & highest & high & moderate & Low & lowest & & & & \\
\hline \multicolumn{10}{|l|}{ Attitudes } \\
\hline $\begin{array}{l}\text { Community supports tourist } \\
\text { activities in rural area }\end{array}$ & 59.0 & 38.0 & 3.0 & - & - & 100 & 4.56 & .55 & Highest \\
\hline $\begin{array}{l}\text { Community shares opinions } \\
\text { together in tourism planning }\end{array}$ & 12.0 & 29.0 & 59.0 & - & - & 100 & 3.53 & .70 & High \\
\hline $\begin{array}{l}\text { Community has knowledge } \\
\text { of management system and } \\
\text { applies local wisdom in } \\
\text { tourism management }\end{array}$ & 3.0 & 46.0 & 51.0 & - & - & 100 & 3.52 & .55 & High \\
\hline \multicolumn{10}{|l|}{ Attractions } \\
\hline $\begin{array}{lrr}\text { Community } & \text { focuses } & \text { on } \\
\text { maintaining } & \text { quality } & \text { of } \\
\text { destination } & & \end{array}$ & 90.0 & 10.0 & - & - & - & 100 & 4.90 & .30 & Highest \\
\hline $\begin{array}{l}\text { Community supports the } \\
\text { establishment of an } \\
\text { agriculture center }\end{array}$ & 45.0 & 6.0 & 49.0 & - & - & 100 & 3.96 & .97 & High \\
\hline $\begin{array}{l}\text { Community promotes } \\
\text { learning activities between } \\
\text { local community and } \\
\text { tourists }\end{array}$ & 3.0 & 47.0 & 50.0 & - & - & 100 & 3.53 & .55 & High \\
\hline
\end{tabular}




\section{Accessibility}

Community improves local landscape

27.0

Community signposts are extensively

Community has security in the village

\section{Accommodation}

Community creates an accommodation theme to interpret local identity

Community arranges and cleans local lodging

Community supports homestay in the village

\section{Activities}

Tourist activities dealing with local agriculture

Tourist activities to build community and tourists

Tourists activities based on the Sufficiency Economy Philosophy

\section{Amenities}

Community creates local dishes from local agricultural products

Community improves infrastructure for tourists (electricity/ water supply)

Local guides

33.0

$69.0 \quad 31.0$

100

$67.0-$

$1.0 \quad 54.0 \quad 45.0$

12.0

$47.0 \quad 41.0$

$\begin{array}{lll}11.0 & 57.0 & 32.0\end{array}$

17.0

$61.0 \quad 22.0$

43.0

$41.0 \quad 16.0$

100

$4.27 \quad .72$

Highest

Community provides vehicles for visiting attractions

\section{Advertising}

Create brochure for agro tourism destination

100

3.16 .66 moderate

Community disseminates agrotourism information in the village

$30.0 \quad 65.0$

$5.0 \quad-$

100

Community collaborates with involve public and private organizations to advertise tourism destination

$\begin{array}{llll}100 & 4.27 & .44 & \text { Highest }\end{array}$

$\begin{array}{llll}100 & 4.37 & .48 & \text { Highest }\end{array}$

$\begin{array}{llll}0 & 4.29 & .45 & \text { Highest }\end{array}$

$\begin{array}{llll}100 & 4.33 & .47 & \text { Highest }\end{array}$

$\begin{array}{llll}100 & 3.56 & .51 & \text { High }\end{array}$

$\begin{array}{llll}100 & 3.71 & .67 & \text { High }\end{array}$

$\begin{array}{llll}00 & 3.79 & .62 & \text { High }\end{array}$

$\begin{array}{llll}100 & 3.95 & .62 & \text { High }\end{array}$

$\begin{array}{llll}00 & 2.80 & .71 & \text { moderate }\end{array}$

$\begin{array}{llll}100 & 3.82 & .65 & \text { High }\end{array}$

$\begin{array}{llll}100 & 4.13 & .72 & \text { High }\end{array}$

$\begin{array}{llllllllll}35.0 & 53.0 & 12.0 & - & - & & 100 & 4.23 & .64 & \text { Highest }\end{array}$ 
Table 2 shows this study's results regarding local community participation in agrotourism. Each aspect of these finding is interpreted as below:

For attitudes, the community supports tourist activities in rural areas at the highest level (average $=4.56$, S.D. $=.55$ ). The community shares opinions together on tourism planning is at a high level (average $=3.53$, S.D. $=.70$ ). The community has a knowledge management system and applies local wisdom in tourism management is also at a high level (average $=3.52$, S.D. $=.55$ ).

In terms of attractions, the community focuses on maintaining the quality of the destination is at the highest level (average $=4.90$, S.D. $=0.30$ ). The community supports the establishment of an agriculture center is at a high level (average $=3.96$, S.D. $=.97$ ). The community promotes learning activities between the local community and tourists is also at a high level (average $=3.53$, S.D. $=.55$ ).

On accessibility, the community improves the local landscape is at the highest level (average $=4.27$, S.D. $=.44$ ). The community signposts are extensively is at the highest level (average $=4.37$, S.D. $=.48$ ). The community has security in the village is at the highest level (average $=4.29$, S.D. $=.45$ ).

On accommodation, the community arranges and cleans local lodging is at the highest level (average = 4.33, S.D. $=.47$ ). The community creates an accommodation theme to interpret local identity is at a high level (average $=$ 3.69 , S.D. $=.46$ ). The community supports homestay in the village is also at a high level (average $=3.56$, S.D. $=.51)$.

For activities, tourist' activities dealing with local agriculture is at a high level (average $=3.71$, S.D. $=0.67$ ). Tourist activities to build connections between the community and tourists is also at a high level (average $=3.79$, S.D. $=.62$ ). Tourist activities based on the Sufficiency Economy Philosophy is at high level as well (average = 3.95, S.D. $=.62$ ).

On amenities, the community creates local dishes from local agricultural products is at the highest level (average $=4.27$, S.D. $=0.72$ ). Local guide are at a high level (average $=3.82$, S.D. $=0.65$ ). The community provides vehicles for visiting attractions is also at a high level (average $=4.13$, S.D. $=.72$ ). The community improves the infrastructure for tourists (electricity/ water supply) is at a moderate level (average $=2.80$, S.D. $=.71$ ).

With regard to advertising, the community collaborate with involve public and private organizations to advertise the tourism destination is at the highest level (average $=4.23$, S.D. $=.64$ ). Creating brochures for the agrotourism destination is at a moderate level (average $=3.16$, S.D. $=.66$ ). The community disseminates the agrotourism information in the village is also at a moderate level (average $=3.25$, S.D. $=.53$ ).

Overall, local community participation in agro tourism is at a high level, with each aspect from the highest level to the lowest level shown in table 3 .

Table 3. Summary of local community participation in 7 aspects of agrotourism

\begin{tabular}{llll}
\hline Items & $\bar{x}$ & S.D. & Interpretation \\
\hline Accessibility & 4.31 & .30 & Highest \\
Attractions & 4.13 & .39 & High \\
Activities & 3.90 & .40 & High \\
Attitude & 3.87 & .32 & High \\
Accommodation & 3.86 & .25 & High \\
Amenities & 3.75 & .34 & High \\
Advertising & 3.55 & .33 & high \\
Total & $\mathbf{3 . 9 1}$ & $\mathbf{0 . 1 4}$ & High \\
\hline
\end{tabular}

Table 3 shows that local community participation in agrotourism in terms of accessibility is at the highest level $($ average $=4.31$, S.D. $=.30)$, while attractions (average $=4.13$, S.D. $=.39)$, activities (average = 3.90, S.D. $=.40)$, attitudes (average $=3.87$, S.D. $=.32$ ), accommodation (average $=3.86$, S.D. $=.25$ ), amenity (average $=3.75$, S.D. $=.34$ ), advertising (average $=3.55$, S.D. $=.33$ ) are all at a high level. 


\subsection{Guideline for Promoting Local Community Participation in the Development of Agrotourism in Ban Mor Village, Sam Sung District, Khon Kaen Province}

In the focus group discussion, ten experts, who included academics, tourism entrepreneurs, representatives of involved public organizations and local philosophers, proposed guideline to promote local community participation in the development of agrotourism in Ban Mor Village, Sam Sung District, Khon Kaen Province.

\subsubsection{Promoting Agrotourism in the Ban Mor Village through Advertising}

To communicate tourism information of about the village, the local community should create a brochure about the agro tourism resources and agro tourism activities in the village. The brochures will be placed in the tourist information centers of tour agencies and at Khon Kaen airport so as to be readily available to tourists easily. An official website disseminates agrotourism in Ban Mor Village should be established because the Internet is a convenient medium through which tourists find information when making a decision these days.

\subsubsection{Improving Facilities to Respond to Tourists' Needs and Expectations}

The local community in Ban Mor Village should arrange lodging or accommodation in line with its theme of being an agricultural village based on the Sufficiency Economy Philosophy. Homestay should be established to allow tourists to experience firsthand living on a sufficiency basis with host community and to consume fresh and organic agricultural produce from their farms. Camping areas can also be set up to attract tourists who wish to experience rural cultural living. Furthermore, involved public organizations should provide budgetary support to improve the local infrastructure, such as electricity or water supply. This not only adds potential to the agricultural destination, but also improves the quality of living for the locals.

\subsubsection{Establishment of a Local Agricultural Learning Center}

A local agricultural learning center will be a place to gather, preserve and share local agricultural wisdom, from traditional agriculture to organic agriculture. Applying the Sufficiency Economy Philosophy which focuses on step-by-step economic development, can improve the quality of life and the quality of the agricultural produce, which is a fundamental concept of Ban Mor Village. This is regarded as the identity of the local community and should be shared with tourists through the local agricultural learning center. This center should also provide demonstrations on the production process of the local agricultural products that are sold to tourists as souvenirs, especially chili paste and chili powder, the recommended dishes of this village.

\subsubsection{Building an Agrotourism Network}

Apart from supporting the preservation and sharing of knowledge about agrotourism and tourism management in the local area, the community should establish and expand and its network with other agricultural areas located in Khon Kaen Province or farther afield. Agrotourism based local community management develops step-by-step at the provincial network level, regional network level and national network level. Building networks fosters the exchange of knowledge and development of agrotourism activities on a wide basis. With more attractive agrotourism activities, more tourists will come to visit Ban Mor Village.

\subsubsection{Promoting the Roles of the Young Members of the Community in Agrotourism}

The young generation of the community represents a significant force in preserving and sharing local wisdom. They play an important role in carrying on local agricultural traditions and disseminating information about agrotourism in order to attain sustainable development. To be an agro tour guide or member of staff at the local agricultural learning center in Ban Mor Village are the best ways to promote the young generation of the community's roles in agrotourism because it also creates jobs, provides incomes in community and establishes the young generation's ties to their homeland. This also decreases the number of people leaving their hometown to find work in the big city.

\section{Conclusion}

In this study, the researchers studied local participation in agrotourism and proposed guidelines to promote local community participation in developing agrotourism in Ban Mor Village, Sam Sung District, Khon Kaen Province, Thailand. A mixed method was applied for the collection and analysis of data. The results showed that, overall, local community participation in agrotourism, is at high level. This includes local community participation in accessibility matters, which is at the highest level (average $=4.31$, S.D. $=.30$ ), as well as in attractions (average $=4.13$, S.D. $=.39$ ), activities (average $=3.90$, S.D. $=.40$ ), attitudes (average $=3.87$, S.D. $=.32$ ), accommodation (average $=3.86$, S.D. $=.25)$, amenity $($ average $=3.75$, S.D. $=.34)$, advertising (average $=$ 3.55, S.D. $=.33$ ), all of which are at a high level.

In focus group discussions, five appropriate guidelines were proposed to promote local community participation 
in the development of agrotourism in Ban Mor Village, Sam Sung District, Khon Kaen Province. There are 1) promoting agrotourism in the Ban Mor village through advertising 2) improving facilities to respond to tourists' needs and expectations 3) establishment of a local agricultural learning center 4) building an agrotourism network 5) promoting the roles of the young members of the community in agrotourism.

\section{Acknowledgments}

The authors gratefully acknowledge the funding support from Bank for Agriculture and Agricultural Co-operatives (BAAC).

\section{Reference}

Ahmad, S. Z., Jabeen, F., \& Khan, M. (2014). Entrepreneurs choice in business venture: Motivations for choosing home-stay accommodation businesses in Peninsular Malaysia. International Journal of Hospitality Management, 36, 31-40. http://dx.doi.org/10.1016/j.ijhm.2013.08.006

Allen, L., Long, P., Perdue, R., \& Kieselbach, S. (1998). The impact of tourism development on residents' perception of community life. Journal of travel research, 27(1), 16-21. http://dx.doi.org/10.1177/004728758802700104.

Briedenhann, J., \& Wickens, E. (2004). Tourism routes as a tool for the economic development of rural areas vibrant hope or impossible dream? Tourism Management, 25(1), 71-79. http://dx.doi.org/10.1016/S0261-5177(03)00063-3

Buhalis, D. (2000). Marketing the competitive destination of the future. Tourism Management, 21(1), 97-116. http://dx.doi.org/10.1016/S0261-5177(99)00095-3

Busby, G., \& Rendle, S. (2000). The transition from tourism on farm to farm tourism. Tourism Management, 21(6), 635-642. http://dx.doi.org/10.1016/S0261-5177(00)00011-X.

France, L. (1998). Local participation in tourism in the West Indian Islands. In E. Law, B. Faulkner, \& G. Moscardo (Eds.), Embracing and managing change in tourism (pp. 223-224). London: Routledge.

Goodwin, H., \& Francis, J. (2003). Ethical and responsible tourism: Consumer trends in the UK. Journal of Vacation Marketing, 9(3), 271-284. http://dx.doi.org/10.1177/135676670300900306

Hjelmar, U. (2011). Consumers' purchase of organic food products. A matter of convenience and reflexive practices. Appetitie, 56(2), 336-344. http://dx.doi.org/10.1016/j.appet.2010.12.019

Jackson, J., \& Murphy, P. (2006). Clusters in regional tourism An Australian case. Annals of Tourism Research, 33(4), 1018-1035. http://dx.doi.org/10.1016/j.annals.2006.04.005

Jurowski, C., Uysal, M., \& Williams, R. (1997). A Theoretical analysis of host community resident reactions to tourism. Journal of travel research, 36(2), 3-11. http://dx/doi/org/10.1177/004728759703600202

Lea, J. (1988). Tourism development in the third world. London: Routledge.

Leiper, N. (1995). Tourism Management. Melbourine: RMIT Press.

Lopez, E. P., \& Garcia, F. J. C. (2006). Agrotourism, sustainable tourism and Ultraperipheral areas: The case of Canary Islands. Journal of Tourism and Cultural Heritage, 4(1), 85-97. Retrieved from http://www.pasosonline.org/Publicados/4106/PS060106.pdf

Maetzold J. (2002). Nature-Based Tourism \& Agritourism Trends: Unlimited Opportunities. Retrieved from http://www.kerrcenter.com/publications/2002_proceedings/agritourism.pdf

Marques, H. (2006). Searching for complementarities between agriculture and tourism - the demarcated wine-producing regions of northern Portugal. Tourism Economics, 12(1), 147-160. http://dx.doi.org/10.5367/000000006776387141

Mongsawad, P. (2010). The Philosophy of the Sufficiency Economy: A Contribution of the Theory of Development. Asia-Pacific Development Journal, 17(1), 123-143. Retrieved from http://www.unescap.org/pdd/publications/apdj_17_1/5_Mongsawad.pdf

Monsef, S. M. S., \& Raji, M. (2013). Assessment of advertising role in Guilan Province Tourism industry development. Interdisciplinary Journal of Contemporary Research in Business, 5(4), 446-452. Retrieved from http://journal-archieves35.webs.com/446-452.pdf

Morrison, A. M. (2013). Marketing and Managing Tourism Destination. London: Routledge.

Murphy, P. E. (1985). Tourism: A Community Approach. New York: Methuen. 
Na Songkhala, T., \& Somboonsuke, B. (2013). Interactions between agro-tourism and Local Agricultural Resources Management: A Case Study of Agro-tourism Destinations in Chang Klang District, Southern Thailand. Discourse Journal of Agriculture and Food Sciences, 1(3), 54-67. Retrieved from http://www.resjournals.org/JAFS/PDF/2013/April/Songkhla_and_Somboonsuke.pdf

Ollenburg, C., \& Buckly, R. (2007). Stated economic and social motivation of farm tourism operators. Journal of Travel Research, 45(4), 444-452. http://dx/doi.org/10.1177/0047287507299574

Ritchie, B. W., \& Inkari, M. (2006). Host Community Attitudestoward Tourism and Cultural Tourism Development: the Case of the Lewes District, Southern England. International Journal of Tourism Research, 8, 27-44. http://dx.doi.org/10.1002/jtr.545

Ritson, C., \& Oughton, E. (2006). Food Consumers and organic agriculture. In L. Frener, \& H. van Trijp (Eds.), Understanding consumers of food products (pp. 254-272). Cambridge: Woodhead Publishing Ltd.

Sam Sung District Agricultural Extension. (2012). Organic farm in Ban Mor village, Sam Sung district, Khon Kaen province. Retrieved from http://sumsung.khonkaen.doae.go.th/image/ safe\%20vegetable/safe\%20vegetable1.htm.

Sebele, L. S. (2010). Community-based tourism ventures, benefits and challenges: Khama Rhino Sanctuary Trust, Central District, Botswana. Tourism Management, 31, 136-146. http://dx.doi.org/10.1016/j.tourman.2009.01.005

Tew, C., \& Barbiere, C. (2012). The perceived benefits of agritourism: The provider's perspective. Tourism Management, 33(1), 215-224. http://dx.doi.org/10.1016/j.tourman.2011.02.005

The Chaipattana Foundation. (n. d.). Philosophy of Sufficiency Economy. Retrieved from http://www.chaipat.or.th/chaipat_english/index.php?option=com_content\&view=article\&id=4103\&Itemid= 293

Tosun, C. (2006). Expected nature of community participation in tourism development. Tourism Management, 27(3), 493-504. http://dx.doi.org/10.1016/j.tourman.2004.12.004

World Tourism Organization. (2004). Indicator of Sustainable Development for Tourism Destinations a guide book. Retrieved from http://www.e-unwto.org/content/x53g07/fulltext?p=1ce65aa8efbe479a87c4d3 eeca903609\&pi $=0 \#$ section $=890050$ \&page $=17 \&$ locus $=48$

\section{Copyrights}

Copyright for this article is retained by the author(s), with first publication rights granted to the journal.

This is an open-access article distributed under the terms and conditions of the Creative Commons Attribution license (http://creativecommons.org/licenses/by/3.0/). 